\title{
Seguro de Pessoas e Acesso ao Mapa \\ GENÉTICO INDIVIDUAL ${ }^{1}$
}

\section{Káren Rick Danilevicz Bertoncello}

Sumário: Introdução. I. Pressupostos do contrato de seguro de pessoas. II. Contrato de seguro de pessoas e acesso ao mapa genético individual pela seguradora: conseqüências. Conclusão. Referências.

\section{INTRODUÇÃO}

A investigação ora pretendida reclama, ainda que em linhas genéticas, a delimitação do assunto a partir das premissas referentes à conceituação, à natureza jurídica, à classificação, às principais características e à positivação nas legislações comparadas, cono forma de fixação dos pontos basilares a autorizar o adentramento da análise sobre o conteúdo da segunda parte do presente estudo, frente aos pressupostos também previamente delineados.

Para tanto, a conceituação do contrato de seguro merece a referência doutrinária do ilustre jurista Pontes de Miranda ${ }^{2}$ ao defini-lo como:

contrato com que um dos contraentes, o segurador, mediante prestação única ou periódica, que o outro contraente faz, se vincula a segurar, isto é, a, se o sinistro ocorre, entregar ao outro contraente soma determinada ou determinável, que corresponde ao valor do que foi destruído, ou danificado, ou que se fixou para o caso do evento previsto.

1 Trabalho apresentado na disciplina de Teoria dos Contratos, 2/2003, Prof $\mathrm{f}^{2}$. Dr. Véra Maria Jacob de Fradera, Curso de Mestrado, Programa de Pós Graduação em Direito da Universidade Federal do Rio Grande do Sul.

2 MIRANDA, Pontes. Tratado de Direito Privado: Parte Especial. Rio de Janeiro: Borsoi, 1964, v. 45, p.274 
A natureza jurídica do contrato de seguro facultativo vem delineada na doutrina de Caio Mario da Silva Pereira ${ }^{3}$ com os seguintes elementos: bilateral, porque gerador de obrigações a ambos os contraentes; oneroso, por criar vantagens e beneficios recíprocos; consensual, porque o novo Código Civil adotou o entendimento de que o instrumento escrito é meio de prova, "suscetivel de suprimento por outros meios"; dirigido, nos moldes dos ensinamentos de Arnold Wald", haja vista o conteúdo do mesmo restar adstrito a aprovação das autoridades administrativas (Superintendência de Segutos Privados); e por adesão, uma vez que a aceitação do segurado ocorrerá sem a discussão do conteúdo das cláusulas contratuais, que, via de regra, são previamente elaboradas e padronizadas pelo segurador. De sua parte, a característica de contrato aleatório, apontada por alguns doutrinadores, é rechaçada na obra de Ernesto Tzirulnik e outros sob o fundamento de que a prestação do segurador não resta identificada pela eventual indenização com a ocorrência do sinistro: "Tal prestação consiste, antes do tudo, no fornecimento de garantia e é devida durante toda a vigência material do contrato. A comutação ocorte entre o prêmio (prestação) e garantia (contraprestação)".

Oportuno o registro da lição de Pontes de Miranda ${ }^{7}$, com base no Código Civil de 1916, onde já estabelecia que a contraprestação do segurador era fundada na segurança oferecida ao segurado, de modo que o pagamento da obrigação principal no caso de ocortência do sinistro é uma eventualidade: "O segurador contrapresta segurando, assumindo a álea".

No que pertine à tutela jurídica incidente nas relações jurídicas securitárias, sob o enfoque versado no presente trabalho, a positivação do negócio jurídico no novo Código Civil, artigos 789 e seguintes, especificamente sobre seguro de pessoas, já existente no diplona civil de 1916, revela o fenômeno trarado pela professora Doutora Cláudia Lima Marques" com base nos estudos de Erik Jaime, denominado de "diálogo das fontes": "Diálogo" porque há influências recíprocas, 'diálogo' porque há aplicação conjunta das duas normas ao mesmo tempo e ao mesmo caso, seja complementariamente, seja subsidiariamente [...]".

Quanto à classificação, a doutrina estabelecia a distinção tradicional entre o seguro de danos e seguro de pessoas, cuja divisão fora adotada pelo legislador pátrio no novo Código Civil, nas Seções II e IlI do Capitulo XV. Nesse sentido, o seguro de danos encontra

3 PEREIRA, Caio Mário da Silva. Instituições de Direito Civil. 11. ed. Rio de Janeiro: Forense, 2003, v. 3, 453 .

4 PERERA, Instituiçōes...

5 WALD, Arnold. Obrigações e Contratos. 12. ed. São Paulo: Revista dos Tribunais, 1995, p.437.

6 TZIRULNMK, Emesto; CAVALCANTI, Flávio de Queiroz B; PIMENTEL, Ayrton. O Contrato de Seguro de acordo com o novo Código Civil Brasileiro. 2. ed. São Paulo: Revista dos Tribunais, 2003, p.30.

? MIRANDA, Tratado, v.45, p.286.

- MARQUES, Cláudia Lima. Diálogo entre o Código de Defesa do Consumidor e o novo Código Civil: do "Diálogo das Fontes" no combate às cláusulas abusivas. Revistá de Dircito do Consumidor, São Paulo, n. 45, p.71-99, jan./mar. 2003. 
destinação à cautela dos eventos danosos ao patrimônio do segurado; ao passo que o seguro de pessoas terá lugar relativamente à vida, à integridade física ou aos familiares dos segurados, motivo pelo qual estes são identificados pelas espécies de seguro de vida, de acidentes pessoais, de acidentes de trabalho e de doença. Daí por que a conceituação do seguro de dano decorrerá da exclusão do bem assegurado não pertencer à modalidade de seguro de pessoas.

As principais características do seguro de pessoas são claramente elencadas pelo jurista português José Vasques:

não terem carácter indemnizatório, isto é: a prestação do segurador não se destina necessariamente à eliminação de um dano ocasionado por determinado evento, antes depende da ocorrência do facto previsto contratualmente para que deva realizar-se;

consistir a obrigação do segurador numa prestação convencionada que não pretende teparar um dano; inexistencia de sub-rogação do segurador nos direitos da pessoa segura contra os eventuais responsáveis pelo sinistro.

Contudo, o próprio autor português a pontà as críticas destinadas às características supramencionadas, já que relativamente ao seguro de doença è cobertura de despesas de tratamento dos seguros de acidentes pessoais há natureza indenizatória e o segurador se sub-roga nos direitos do lesado.

Na mesma linha, colacionamos os ensinamentos do ilustre jurista francês Louis Josserand ${ }^{i 0}$, transcrevendo a conceituação formulada sobre a modalidade de seguro ora investigada e registrando, de antemão, a exposição do autor no que diz com os princípios gerais do contrato de seguro de pessoas à semellança do conteúdo das caracteristicas apontadas por Jose Vasques:

Los seguros de personas son todos los tipos de seguros que tienden a garantizar, mediante primas o cotizaciones, la entrega de un capital o el servicio de una renta con ocasión de una eventualidad que interesse, no a los bienes, sino a la persona misma: llegada a tal edad, matrimonio, enfermedad, fallecimiento, accidente corporal.

\footnotetext{
"VASQUES, José. Contrato de Seguro. Coimbra: Coimbra, 1999, p.38.
}

10 JOSSERAND, Louis. Derecho Civil. Buenos Aires: Bosch, 1951, v.2, t.2, p.325. 
Noticia Pedro Alvim ${ }^{11}$, no que pertine à positivação do negócio jurídico estudado, que o primeiro diploma legal a inserir dispositivos sobre seguros terrestres foi o Código da Holanda de 1838. A partir daí a inclusão de dispositjvos sobre seguros matíímos e terrestres adveio com o "Código italiano de 1882; o romeno, de 1887; o português, de 1888; o espanhol, de 1889", entre outros.

No mais, o tratamento destinado, atualmente, ao tema em apreço pelo ordenamento jurídico italiano resta consubstanciado no artigo 1.919 e seguintes do Codice Civile. Já o ordenamento francês dispõe de diploma específico a tutelar as relações jurídicas atinentes à esfera securitária de pessoas, em especial, o título III do Code des Assurances. Outrossim, o ordenamento jurídico português dispõe de disciplina sobre o tema no Código Civil de 1966 e, mais recentemente, através do DL 94-B/98 de 17 de abril, artigos 188 a 193, que tratou da lei aplicável ao contrato de seguro.

\section{PRESSUPOSTOS DO CONTRATO DE SEGURO DE PESSOAS}

A identificação dos pressupostos integrantes do negócio jurídico em estudo é subdividida doutrinariamente em requisitos subjetivos, objetivos e formais, segundo a classificação proposta por Maria Helena Diniz ${ }^{12}$ e Caio Mário da Silva Pereira ${ }^{13}$.

No que diz com o aspecto subjetivo, a condição de segurador é reconhecida exclusivamente às pessoas jurídicas autorizadas pelo Governo Federal, nos moldes da previsão do artigo 757, patágrafo único, do Código Civil vigente, cuja disciplina legal, sem dispositivo correlato no Código Civil de 1916, expressa o teor do Decreto - Lei n².063/40, artigo $1^{\circ}$, e do Decreto $n^{\circ} 60.459 / 67$, artigos 42 , parágrafo único, e 48 . Neste particular, de acordo como autor Sílvio Luis Ferreira da Rocha ${ }^{14}$, atualmente apenas as "empresas organizadas sob a forma de sociedade anônima" poderiam atuar na qualidade de seguradoras. É que, como bem explica Orlando Gomes", "em razão das próprias exigências técnicas de ordenação e de funcionamento do seguro", a pessoa física que assumisse "a posição de segurador não teria condições de atender aos objetivos do seguro, se permitido the fosse realizá-lo".

Tais exigências sobre as condições da figura do segurador frente à natureza da atividade desempenhada, revelam a lição de Cesare Vivante, ${ }^{16}$ consagrado jurista italiano, responsável

${ }^{11}$ ALViM, Pedro. O Contrato de Seguro. Rio de Janeiro: Forense, 1983, p.42.

${ }^{2}$ DINIZ, Maria Helena. Tratado Teórico e Prático dos Contratos. 4. ed. Săo Paulo: Saraiva, 2002 , p. 449.

13 PEREIRA, Instituições, p.454.

I ROCHA, Silvio Luis Ferreira da. Curso Avançado de Direito Civil. São Paulo: Revista dos Tribunais, 2002 , v. 3, p.365.

${ }^{15}$ GOMES, Orlando. Contratos, 16. ed. Rio de Janeiro: Forense, 1995, p.417.

16 VIVANTE, Cesare. Del Contratto di Assicurazione. Torino: Unione Tipográfico Editrice Torinese, 1936 , p. 11. 
pela proposição da teoria jurídica, pertinente aos pressupostos do segurador, fundada no ordenamento jurídico italiano e na função econômica dos seguros:

Ciò solo essenziale che l'assicuratore si proponga di esercitare l'ufficio di ripartizione che è caratteristico della sua industria, distribuendo i premi raccolti da um gruppo numeroso di assicurati fra coloro che sono colpiti dai rischi designati nel contratto.

Já a figura do segurado vem delinitada à semelhança dos requisitos legais destinados à obtenção da capacidade civil, visto que a natureza do ato jurídico de contratação do seguro caracterizaria exercício de ato de administração, nos quais os menores pactuariam através dos representantes legais respectivos. Daí por que o negócio restaria firmado exclusivamente por pessoas civilmente capazes ${ }^{17}$.

A condição de beneficiário, no caso do seguro de pessoas, encontra algumas particularidades em vista das vedações legais dispostas nos artigos 550 e 1.801, MI, ambos do Código Civil vigente, motivo pelo qual não podem ser beneftciários a pessoa legalmente inibida de receber doação do segurado, nas hipóteses de cônjuge adúltero em favor de seu cúmplice ou do seu concubino, consoante assertiva perpetrada por Maria Helena Diniz. ${ }^{18} \mathrm{De}$ sua parte, Voltaite Marensi ${ }^{19}$ rejeita a interpreração formulada pela jurista retrocitada, asseverando a inexistência de texto legal expresso que vede a condição de beneficiários ao cúmplice ou ao concubino, destinando a solução à exegese que resultatá dos Tribunais Superiores.

Outrossim, Maria Helena Diniz registra o tratamento jurisprudencial endereçado aos precedentes relativos às hipóteses de separações judiciais e de separações fáticas em que um dos consortes contrata seguro em favor do companheiro, cujo entendimento restou normatizado pelo artigo 793 do atual Código Civil. Por fim, as vedaçôes insculpidas nos artigos 1.814 e 1.818 do Código Civil wigente impedem a atuação de beneficiário a exemplo dos casos elencados como incapacidade para suceder.

O consentimento dos contraentes é resultante da proposta formulada pelo segurado, esta já elaborada previamente pelo segurador, dada a natureza de contrato por adesão do negócio em aprcço, e da aceitação promovida pelo segurador no prazo de noventa dias, conforme Decreto - Lei $\mathrm{n}^{\circ} 2.063 / 40$, artigo 108. Neste sentido, julgamos pertinente o registro das diretivas citadas pela jurista Cláudia Lima Marques ${ }^{20}$, no que tange à interpretação do negócio jurídico desta natuteza:

17 ROCHA, Curso avânçado...

${ }^{18}$ DINIZ, Tratado..., p.443.

19 MARENSI, Voltaire. O Contrato de Seguro à luz do novo Código Civil. 2. ed. Porto Alegre: Síntese, 2002, p. 78 .

20 MARQUES, Cláudia Lima. Contratos no Código de Defesa do Consumidor. 4. ed. São Paulo: Revista dos Tribunais, 2002, p.394-395. 
Aq̣ui há de se presumir a boa - fé subjetiva dos consumidores e se impor deveres de boa - fé objetiva (informação, cooperação e cuidado) para os fornecedores, especialmente tendo em conta o modo coletivo de contratação e por adesão.

Os pressupostos objetivos do contrato de seguro estão relacionados com a licitude e a possibilidade do objeto, este sendo identificado pelo risco contra o qual se pactua o seguro e entendido como "um acontecimento futuro previsto no contrato. Não é necessário que o evento seja incerto; basta a incerteza quanto ao momento em que se verificará". ${ }^{21} \mathrm{~A}$ existência do risco é pressuposto essencial do contrato, sob pena de nulidade por falta de objeto, de acordo com os ensinamentos de Orlando Gomes.

O artigo 773 do novo Código Civil estabelece sanção com pagamento em dobro do prêmio estipulado para o caso do segurador que firma o contrato de seguro tendo conhecimento sobre a inexistência do risco ao tempo da celebração do contrato. Em contrapartida, havendo mera ignorância sobre a inexistência do risco, "a anulação resultará na devolução da quantia paga a título de prêmio, sem a imposição da penalidade"..22

A visão do conceito e da delimitação do risco deve visualizar a noção econômica de seguro, a qual permite a distinção entre a noção econônica de operação de seguro e o conceito jurídico de contrato de seguro,

já que enquanto este último traduz apenas a ligação individual que entre a seguradora e o segurado se estabelece, à operação de seguro é essencial a existência de uma colectividade de pessoas correndo riscos homogeneizados, compensados pelas leis da estatística, e cque aceitan pagar adiantadamente os prémios que se destinam a suportar os danos sofridos por algumas de entre elas. ${ }^{23}$

É que, nos termos da explicação do autor José Vasques, do ponto de vista unitário do contrato de seguro, a pactuação do risco entre os contratantes é irrelevante à operação econômica global subjacente ao contrato. Contudo, julgamos impositjvo, neste particular, uma breve abordagem da visão econômica do direito, esta sedimentada nas lições de Cento Veljanorski ${ }^{24}$, visto que a relação jurídica firmada entre segurador e segurado, em verdade, retrata uma operação econômica em que a troca patrimonial e a observância de cálculos estatísticos resultam evidentes, mormente, pela atuação na qualidade de pilares da estipulação do custo da contratação dos seguros. É que a seguradora, enquanto empresa responsável

\footnotetext{
27 GOMES, Contratos..., p.418.

22 ROCHA, Curso avançado..., p.366.

23. VASQUES, Contrato..., p,93.

24 VILJANOVSKI, Cento. A Ecomomia do Diraito e da Lai. Rio de Janeiro: Instituto Liberal, 1994 , p.47.
} 
pela manutenção da idoneidade financeira no intuito de preservar a viabilidade da contraprestação de segurança ao contraente - consumidor, desempenha a atividade no mercado com base nas estatísticas obtidas que the proporcionen a previsão sobre a média de ocorrências de sinistros ou tendências, já que o princípio no qual a seguradora consubstancia a atividade é a administração e a distribuição do custo do preço dos prêmios percebidos e aquele decorrente dos sinistros ocorridos. Nesta linha de entendimento, consignamos que a relação individual do contrato firmado entre segurador e segurado, frente ao todo, merece apreciação como operação integrante dos parânetros estatísticos observados para a delimitação do preço dos prêmios e demais custos advindos da relação securitária, pois a lealdade e a cooperação de ambas as partes serão projetadas na análise de custo - benefício:

Se as pessoas não se comportam de maneiras previsiveis, então a idéia de que podemos regulamentar a sociedade por meio de leis e incentivos se torna impraticável. Mas toda a base dos negócios, da lei e da atividade social se sustém na hipótese de que as pessoas, na média, de fato reagem de maneiras previsiveis. Sabemos, por exemplo, que quando o preço de certa marca de automóvel se eleva relativamente a outras marcas, menos carros da marca cujo preço aumentou serão comprados. A hipótese da racionalidade é usada pelos economistas não como uma descrição do comportamento humano, e sim como uma maneira de identificar o componente previsivel da reação do individuo médio que compóem um grupo. Esse uso da hipótese da racionalidade considera o homem econômico como média ponderada do grupo de individuos em exame. Permite, assim, a existência de diferenças marcantes nas reações individuais.

Ademais, a declaração do risco retrata um "dever pré-contratual" 25 , o qual encontra substrato no princípio da boa - fé, enquanto orientador da relação obrigacional, tendo em vista a repercussão que ocasionará na economia do contrato pela delimitação das conseqüências assumidas, a partir da apreciação a priori viabilizando a avaliação do tisco e o cálculo do prêmio.

Da mesma forma, consignamos que os riscos pactuados no negócio são mutáveis, podendo sofrer alterações ao longo da relação contratual. Caso ocorra diminuição nos tiscos, "não haverá modificação do conteúdo do contrato. Se eles aumentarem, também, em linha de princípio, não haverá modificação no conteúclo do contrato, salvo a existência no contrato de cláusula expressa que autorize o segurador a solicitar um aumento do prêmio pago pelo aumento dos riscos". Tal assertiva não mais dispõe de disciplina especifica no atual Código

\footnotetext{
25 VASQUES, Contrato.., p.211.

26 ROCHA, Curso avançado..., p.367.
} 
Civil, entretanto, decorre da principiologia prevista no Código de Defesa do Consumidor em beneficio ao consumidor, hipossuficiente por presunção.

Por fim, quanto à função indenizatória e o interesse nos seguros de pessoa, há alouns seguros integrantes da modalidade ora estudada que dispõem de caráter indenizatório, onde, em tese, deveria impedir a contratação de vários seguros sobre o mesmo interesse, segundo a doutrina de Emesto Tzirulnik e outros ${ }^{27}$, referindo os contratos de seguro que garantem o pagamento de diárias no caso de afastamento das atividades laborais por motivo de saúde ou, ainda, contrato de seguro de vida, em que os prêmios pactuados resultem em valores que representem vantagem desmedida ao beneficiário na ocorrência do sinistro, comparativamente ao padrão de vida até então experimentado pelo segurado ou seu beneficiátio. Para tanto, expõe o autor, a atuação do artigo 421 do Código Civil vigente como parâmetro limitador da liberdade de contratar pelo segurado, prevista no artigo 789 do mesmo diploma legal, relarivamente à quantidade e ao valor do prêmio pactuado. Ainda, agregada a essa interpretação, colacionamos a disciplina do dispositivo 795 do novo Código Civil, pela qual o legislador pátrio vedou a possibilidade de transação sobre redução do capital segurado, destinando maior segurança ao contraente - consumidor, como bem elucida Voltaire Marensi ${ }^{28}$ :

Esta situação visa a beneficiar, muitas vezes, situações em que o segurado é premido por questôes de foro intimo e que não se pode relacionar com o contrato securitário, sob pena de se desnaturar a própria essência do contrato de seguro, que no fundo é de mútuo, isto é, destinado a atender as necessidades do segurado ou de sua família em contraprestação ao prêmio pago.

A esse propósito, impositivo o destaque da lição de Celso Marcelo de Oliveira ${ }^{29}$, onde o autor aduz a ausência de caráter indenizatótio sobre o contrato de seguro de pessoas sob o fundamento de que o negócio independe de qualquer limitação, variando de acordo com a vontade e as condições financeiras do segurado, que poderá pactuar tantos seguros quanto desejar. Para tanro, argumenta a impossibilidade de atribuição de valor à vida ou às faculdades humanas.

Na mesma esteira, a lição de Caio Mário da Silva Pereira ${ }^{30}$ aponta como pressupostos objetivos específicos os "ilicitos especiais", em matéria securitária, "como o seguro por mais do que valha a coisa segurada, ou a pluralidade de seguros sobre o mesmo bem (seguro cumulativo), com exceção do de vida", consoante previsão dos artigos 781, 782 e 789, todos do Código Civil vigente.

\footnotetext{
${ }^{27}$ TZIRULNIK; CAVALCANTT; PIMENTEI, O contrato..., p.162.

${ }^{2 B}$ MARENSI, O contrato..., p.79.

21) OLIVIIRA, Celso Marcelo de. Contrato de Seguro. São Paulo: Campinas, 2002, p.11.

${ }^{30}$ PEREIRA, Instituiçōes..., p.455-456.
} 
No que diz com o terceiro e último pressuposto, os pressupostos formais correspondem à exigibilidade legal da formalização do negócio jurídico na forma escrita, segundo preceituam os artigos 759 e 760 do Código Civil de 2002 , não obstante a comprovação do contrato possa ser efetivada através do pagamento do prêmio pelo segurado, de acordo com o artigo 758 do mesmo diploma. É que as condições específicas do negócio devem estar expressamente estabelecidas, em virtude de dispositivo de lei.

Assim, a formação do contrato terá validade somente com a assinatura da proposta pelo interessado ou o representante, sendo admitida a "proposta tácita" apenas ná hipótese de continuação do negócio já contratado anteriormente ${ }^{33}$, caso ocorra a emissão da nova apólice ou a declaração de prorrogação e o segurado efetue o pagamento do prêmio respectivo. Consignamos, ainda, que o inf́cio da vigência do negócio pode darar de momento distinto daquele em que restara formado o contrato, uma vez que a data da formação deste é contada da emissão da apólice.

Estabelecidas as premissas do contrato de seguro de pessoas, a investigação sobre os limires de acesso aos dados genéticos dos segurados frente aos fundamentos conformadores do negócio jurídico ora estudado torna-se autorizada.

\section{CONTRATO DE SEGURO DE PESSOAS E ACESSO AO MAPA GENÉTICO INDIVIDUAL PELA SEGURADORA: CONSEQÜÊNCIAS}

Observada a tecnicidade do assunto relacionado aos códigos genéticos, cuja apreciação no presente estudo decorre do corte de conhecimento com ingresso nas ciências médicas, segundo a linguagem metodológica, resulta imperativa a conceituação do termo "genoma" com o fito de elucidar a pretendida evolução no raciocínio atinente à influência destes nos contratos de seguro de pessoas.

Segundo o médico Carlos Miranda Chagas" "Genoma é o conjunto de todos os genes que constituem o patrimônio genético de um ser vivo". Mais, explica o autor que a pesquisa pertinente ao "Projeto Genoma Humano" adveio do consórcio internacional responsável pela proposta de aceleração da decodificação total do DNA num prazo de 15 anos, "para identificar as seqüências de suas bases quimicas (ou "letras"), com a finalidade de mapear todos os 100 mil genes do organismo humano (dentre os quais, cerca de 30 a 40 mil ditos funcionais\}" [...] No entanto, noticia o autor que a conclusão ocorrera dois anos antes do término do prazo previsto, apontando que, não obstante o mapeamento, a "interpretação" dos genes mapeados não fora efetivada, de modo que a média de identificação dos genes associados a doenças restaria em 100 genes ao ano.

3 Ibidem, p.456.

${ }^{32}$ CHAGAS, Carlos Miranda, Genoma Humano e Seguro de Pessoas. Revista do IRT3, Rio de Janeiro, n. 292, p.9.15, abr./jun. 2003. 
Outrossim, registramos que a investigação sobre os fatores desencadeantes de patologias no ser humano concluiu pela existência de fatores internos e externos, de acordo com a doutrina de Matt Ridley", ao expressar: "A mente estimula o corpo, que estimula o genoma". Assim, do ponto de vista interno, tal fator estaria relacionado com o código genético humano; enquanto os fatores externos adviriam, com base na pesquisa citada pelo autor inglês, no padrão social vivido pelo individuo, in verbis:

As pessoas são muito parecidas com os macacos. A descoberta de que os macacos em posições inferiores na hierarquia do bando têm doença cardíaca surgiu logo após á descoberta muito mais surpreendente de que os funcionários públicos britânicos que trabalham em Whitehall também adquirem doença cardíaca na proporção da inferioridade de sua posição na hierarquia burocrática. Em um estudo demorado e abrangente de 17 mil funcionátios públicos, surgiu uma conclusão quase inacreditável: o status do cargo de uma pessoa era um indicador melhor de sua probabilidade de um ataque cardíaco do que a obesidade, o tabagismo ou a pressão alta. Uma pessoa em um cargo inferior, como um zelador, eta quase quatro vezes mais propensa a ter um ataque cardíaco do que um secretário petmanente no topo da hierarquia. De fato, mesmo que o secretário permanente fosse gordo, hipertenso ou fumante, ainda assim ele seria menos propenso a sofrer um ataque cardíaco em uma certa idade do que um zelador magro, não - fumante e com pressão arterial baixa. Exatamente o mesmo resultado surgir de um estudo semelhante de um milhão de empregados da Bell Telephone Company na década de 1960.

Em verdade, considerada a assertiva sobre a influência da mente no corpo e, por conseguinte, no genoma, agregada à pesquisa de campo referida por. Matt Ridley, as emptesas seguradoras obteriam o quadro estatístico científico a partir da completa investigação multifatorial da vida do segurado.

No mesmo sentido, destacamos a lição do médico Carlos Miranda Chagas ao asseverar que:

[...] já sabemos que as pessoas trazem essas doenças desde o momento de sua concepção, mas sua manifestação é dependente de predisposição individual e de fatores externos, inexistindo um padrão etário para a expressão dessas doenças. ${ }^{34}$

${ }^{33}$ RIDLEY, Matt. Genoma. Rio de Janeiro: Record, 2001, p.184.

${ }^{34}$ CHAGAS, Genoma..., p. 12. 
Ultrapassada a análise da formação e da influência do código genético, cumpre - nos adentrar no exame das consequências decorrentes da possibilidade de acesso das seguradoras sobre o mapa genético individual, no que pertine aos contratos de seguro de pessoas.

Como bem salienta o autor Catlos Miranda Chagas, anteriormente mencionado, caso o acesso seja negado às seguradoras a seleção previamente realizada permanecerá, via de regra, com base na "pesquisa clínica de antecedentes patológicos, pessoais e familiares, bem como na investigação e intexpretação dos resultados de exames complementares [...]". ${ }^{35}$

De outro lado, havendo a possibilidade do segurador conhecer o mapa genético do segurado, duas hipóteses podem ser aventadas: a) se o mapeamento das doenças genéticas for completado, realidade nos dias de hoje inexistente, o segurador terá ao seu dispor a plena capacidade de avaliação sobre a probabilidade de implementação do sinistro assegurado ao contraente, que, partindo-se do pressuposto de que não contratará com os indivíduos que dispõem de média ou de grande potencialidade do acometimento de doenças genéticas, ocasionaria a ausência do objeto do contrato de seguro em virtude da inexistência ou remota existência do risco, sem prejuizo de consideraçòes atinentes às conseqüências advindas com a descoberta na íntegra do mapeamento das doenças: "A meta complementar é, gradativamente, encontrar e disponibilizar os meios de prevenir a manifestação e curar precocemente não só essas doenças genéticas, mas também todas as outras de natureza multifatorial"36; b) não havendo o mapeamento completo das doenças genéticas, mas observada a informação do conhecimento de número razoável de doenças com constante crescimento nas descobertas pela pesquisa científica, o acesso aos mapas individuais pela seguradora proporcionaria a faculdade destas de evitar a contratação com indivíduos potencialmente capazes de incursão no sinistro assegurado.

Ora, por certo que a presente inves tigação ensejaria estudo específico sobre a abordagem da provável infringência ao direito fundamental do homem à privacidade e, ainda, a necessidade da delimitação do direito à informação (este visto sob ambos os ângulos). Contudo, os limites formais da presente exposição prejudicariam o exame pormenorizado da respectiva doutrina e atuais reflexões sobre a ponderação dos argumentos conflitantes, cumprindo, apenas, o destaque sobre a elaboração de instrumento internacional que privilegiou a proteção da dignidade humana "(de la personne et de l'espèce), apparue en France en 1994 et consacrée à l'échelon international em 1997 (Convention d'Oviedo sous l'égide de l'UNESCO)", ${ }^{37} \mathrm{Na}$ mesma linha, positivação anterior é revelada pelo magistrado italiano Francesco Maria Cirillo ${ }^{36}$

${ }^{35}$ Tbidem, p.11.

${ }^{36}$ CHAGAS, Genoma..., p.12.

${ }^{37}$ A propósito ver FRAISSEIX, Patrick. Lâ Protection de la Dignité de la Personne et de l'Espèce Humaines dans le Domaine de la Biomedicine: l'exemple de la Convention d'Oviedo. Revue Intemationale de Droit Comparé, Paris, n. 2, p.371-413, avr./juin 2000.

38 CIRILLO, Francesco Maria. La Progressiva Conoscenza del Genoma Umano: Tutela della Personna e Problemi Giuridici Connessi con la Protezione dei Dati Genetici. Rivista di Diritto Civile, Padova, n. 3, p.399.419, magg./ging. 2002. 
ao estudar o tema do genoma humano relacionado ao contrato de seguto e asseverar a prevalência da proteção da dignidade humana como limite ao desenvolvimento da atividade econômica, no que diz com à seguradora pretender o acesso ao mapeamento genético do contratante:

Nel senso ora indicato si colloca, com chiarezza indiscutibile, la Risoluzione 16 marzo 1989 del Parlamento europeo più volte citata, ove ai numeri 19 e 20 si afferma da un lato che gli assicuratori non hanno il diritto di chiedere agli assicurati lo svolgimento di test genetici che siano condizione per la stipula di un contratto, e dall'altro che i primi non possono neppure pretendere di essere informati su dati genetici a conoscenza dei secondi.

Não obstante isso, a proposta aqui formulada objetiva a avaliação relativa ao objeto do contrato de seguro e às conseqüèncias sobre a relação obrigacional entabulada entre seguradora e segurado - consumidor, em especial, a presença do risco, diante da possibilidade de minoração substancial nas hipóteses de ocorrência do sinisrro $\mathrm{cm}$ face da possibilidade de acesso da seguradora aos mapas genéticos individuais, que propiciarão, por conseguinte, um negócio jurídico exageradamente favorável à seguradora, diante da circunstância dos riscos passarem a abranger, com maior probabilidade, a esfera dos demais infortúnios a que o segurado possa ser acometido, favorecendo-as em vista do prévio conhecimento sobre a provável evolução na saúde do segurado.

Diante do exposto, adentrando a definição de risco, enquanto objeto do negócio jurídico em exame, encontramos amparo doutrinário nos ensinamentos de Pedro Alvim ${ }^{35}$ ao apontar o conceito elaborado por. Amilcar Santos:

[...] deve ser um acontecimento possivel, mas futuro e incerto, quer quanto à sua ocorrência, quer quanto ao momento em que se deverá produzir, independente da vontade dos contratantes. É o evento incerto, ou de data incerta, independente da vontade das partes, e contra o qual é feito o seguro.

O autor prossegue, criticando a expressão "independente da vontade dos contratantes" sob o argumento de que, atualmente, são pactuadas coberturas, nas hipóteses de responsabilidade civil, nos contratos de seguro para o caso de culpa do segurado. Daí por que apresenta nova definição: "Pode-se conceituar, então, o risco segurável como o acontecimento possível, futuro e incerto, ou de data incerta, que não depende somente da vontade das partes". ${ }^{48}$

39) ALVIM, O contrato.., p.215.

AL ALVM, Contratos... 
Nesse contexto, podemos afirmat que o eventual conhecimento pela seguradora sobre o mapa genético individual do segurado, por evidente, não retiraria o objeto do negócio, vez que mantida a possibilidade do advento de outros infortúnios ao segurado. Mas algunas reflexões advindas das conseqüências prováveis sobre o contrato de seguro de pessoas restariam autorizadas, a saber; a) os contratos são delineados com base no princípio da igualdade material, pois o segurado paga o prêmio de acordo com as condições pessoais de idade, da atividade laboral desempenhada, entre outros fatores; b) observados os dados estatísticos apresentados por Carlos Miranda Chagas, nos dias de hoje, ainda que as seguradoras dispusessem dos dados genéticos individuais dos segurados, ou pretensos segurados, não contariam com a totalidade de identificação do mapeamento das doenças genéticas em virtude da limitação no campo científico, de modo que persistiria ampla dimensão na álea do contrato; c) o acesso aos mapas genéticos individuais, na atual conjuntura, já viabilizaria a classificação dos indivíduos segundo grau maior ou menor de probabilidade da ocorrência do sinistro e acarretaria a ponderação das estatísticas projetadas pelas seguradoras sobre a fixação do preço dos prêmios; d) "considerada a relação obrigacional como um processo" "4! ainda que as seguradoras não disponham de acesso aos dados genéticos dos pretensos segurados, o dever de lealdade e de informar previamente as doenças genéticas já conhecidas pelo contraente, assim como de informar a seguradora na hipótese de vir a tomar conhecimento sobre alguma alteração que repercuta na relação entre risco e prêmio é inafastável, como bem assevera Christoph Fabian"4 "O segurado deve informat sobre todo incidente que aumenta o risco. Para que a regra fique praticável, o segurado não precisa avisar qualquer alteração pequena do risco. Só deven ser informadas as agravações essenciais"; e) por derradeiro, o acesso ao mapeamento genético individual pelas seguradoras ensejaria o questionamento acerca da admissibilidade de atribuição de patamares na prestação e na contraprestação do negócio jurídico a partir da eugenia, onde a consequiência concreta seria revelada pela fixação do preço do prêmio com base na qualidade do código genético pessoal, ocasionando a sobrecarga valorativa àquele contraente detentor de mapa com maior chance de incursão no sinistro pactuado.

\section{CONCLUSÃO}

O assunto proposto no presente estudo retrata a teflexão inicial sobre as prováveis conseqüências condizentes à evolução do mapeamento das doenças pela ciência médica e o eventual acesso das seguradoras aos dados genéticos individuais dos segurados ou proponentes do contrato de seguro de pessoas.

4 SILVA, Clóvis V. do Conto e. A Obrigaçăo cotno Processo. São Paulo: Josể Bushatsky, 1976, p.5.

42 FABIAN, Christoph. O Dever de Informax no Direito Civil. São Paulo: Revista dos Tribunais, 2002, p.128. 
Após a breve exposição sobre o tema, entendemos que algumas premissas devam ser concluídas, não obstante o resultado da proposição principal do estudo permaneça sem soluções peremptórias em face da necessidade de maior investigação sobre o assunto a permitir soluçōes responsáveis e cientificamente (sustentáveis), são elas:

a) a atividade desempenhada pelas seguradoras, enquanto tecnicamente profissionalizada, dispõe de aptidão para a atuação no mercado com disponibilidade de dados estatísticos, estes ainda que limitados, que viabilizem a conciliação da preservação da finalidade do contrato de seguro, assim como da idoneidade patrimonial da seguradora para contraprestar a obrigaçăo na eventual ocorrência do sinistro, o que pressupõe, simultaneamente, a continuidade da percepção do lucro no exercicio da atividade empresarial. Não é outra a conclusão dos juristas franceses Marcel Planiol e Georges Ripert, ${ }^{43}$ na década de 30, quando concluíram as condições de atuação das seguradoras no mercado:

Au moyen du calcul des probabilités, l'entreprise d'assurances qui réunit um très grand nombre de risques de même nature connait à l'avance de façon approximative la proportion dans laquelle ces risques se réaliseront effectivement. Alors que l'assuré ne sait aucunement s'il sera atteint par le risque qu'il redoute, la part de l'inconnu est relativement très réduite pour l'assureur.

b) a própria apreciação sobre a natureza e os fundamentos do surgimento contrato de seguro autorizam, em sede de juízo inicial, a conclusão sobre a limitação do acesso dos mapas genéticos às seguradoras, mormente, ante a ponderação inserida na letra " $e$ ", da segunda parte do trabalho em questão, pois a desconfiguração do contrato decorreria da oneração àqueles segurados detentores de código genético desfavorável, do ponto de vista da seguradora, em franca infringência à finalidade social do negócio.

Nessa linha de raciocínio, destacamos os fundamentos responsáveis pela origem do contrato de seguro, enquanto instrumento de tranqüilização social fundado na solidariedade e na distribuição eqüitativa dos custos, uma vez que "implica agrupamiento de personas, comunidad de riesgos y contribución a un fondo, es la que permite amortiguar los efectos del álea, neutralizar la entidad de los riesgos realizados (siniestros), fraccionar o diluir sus consecuencias." "Hi A contrário senso, estar-se-ia incidindo na esfera da especulação pura, caso admitida a eventual assunção do risco por um particular sobre determinada pessoa na condição de segurado, visto a ausência de idoneidade patrimonial, de um lado, e a aposta na sorte alheia, por ourro.

${ }^{43}$ PLANIOL, Marcel; RIPERT, Georges.Traité Pratique de Droit Civil Français. Paris: LGDJ, 1932, 557.

${ }^{44}$ STIGLITZ, Rubén S. Derecio de Seguros. Buenos Aires: Abeledo Perrot, 1997, v 1, p.21. 


\section{REFERENNCIAS}

AlBUQUERQUE, João Batista Torres de. Seguros no Direito Brasileiro. Campinas: Bookseller, 2002. v.1.

ALVIM, Pedro. O Contrato de Seguro. Rio de Janeiro: Forense, 1983.

CHAGAS, Carlos Miranda. Genoma Humano e Seguro de Pessoas. Revista do IRB, Rio de Janeiro, n. 292, p. 9-15, abr./jun. 2003.

CIRILLO, Francesco Maria. La Progressiva Conoscenza del Genoma Umano: Tutela della Persona e Problemi Giuridici Connessi con la Protezione dei Dati Genetici. Rivista de Diritto Civile, Padova, n. 3, p.399-419, magg./giug. 2002.

CLARET, Hélène. Intérpretation des Contrats d'Assurance et D roit de la Consommation. Recueil Dalloz, Paris, n. 38, p.2600-2602, oct. 2003.

DELGADO, José Augusto. Comentários ao Novo Código Civil. Rio de Janeiro: Forense, 2004. v. 11, t. 1

DINIZ, Maria Helena. Tratado Teórico e Prático dos Contratos. 4. ed. São Paulo: Saraiva, 2002.

FABIAN, Christoph. O Dever de Informarno Direito Civil. São Paulo: Revista dos Tribunais, 2002.

FRAISSEIX, Patrick. La Protection de la Dignité de la Personne et de l'Espèce Humaines dans le Domaine de la Biomédicine: l'exemple de la Convention d'Oviedo. Revue Internationale de Droit Comparé, Paris, n. 2, p.371-413, avr./juin 2000.

GOMES, Orlando. Contratos, 16. ed. Rio de Janeiro: Forense, 1995.

JARDIM, Antônio Guilherme Tanger. O Consumidor e o Contrato de Seguro. Revista de Direito do Consumidor, São Paulo, n. 26, p.27-32, abr./jun.1998.

JOSSERAND, Louis. Derecho Civil. Buenos Aires: Bosch, 1951. v. 2, t. 2.

KRIGER FILHO, Domingos Afonso. O Contrato de Seguro no Direito Brasileiro. São Paulo: Labor Júris, 2000.

LEIVAS, Paulo Gilberto Cogo Leivas. A Genética no Limiar da Eugenia e a Construção do Conceito de Dignidade Humana. In: MARTINS - COSTA, Judith (Org.). A Reconstrução do Direito Privado. São Paulo: Revista dos Tribunais, 2002. 
MARENSI, Voltaire, O Contrato de Seguro à luz do novo Código Civil. 2. ed. Porto Alegre: Síntese, 2002.

MARQUES, Cláudia Lima. A Abusividade nos Contratos de Seguro-Saúde e de Assistência Médica no Brasil. Revista da AJURIS, Porto Alegre, n. 64, p.34-77, jul. 1995.

. Contratos no Código de Defesa do Consumidor. 4. ed. São Paulo: Revista dos Tribunais, 2002.

- Diálogo entre o Código de Defesa do Consumidor e o novo Código Civil: Do "Diálogo das Fontes" no Combate às Cláusulas Abusivas. Revista de Direito do Consumidor, São Paulo, n. 45, p.71-99, jan./mar. 2003.

MARTINS - COSTA, Judith. O Co-Seguro no Direito Brasileiro: Entre a Fragilidade da Prática e a Necessidade de Reconstrução Positiva do Instituto. Revista da Faculdade de Direito da Universidade Federal do Rio Grande do Sul, Porto Alegre, n'21, p.161-178, março/2002.

MIRANDA, Pontes. Tratado de Direito Privado. Parte Especial. Rio de Janeiro: Borsoi, 1964. v. 45.

OLIVEIRA, Celso Marcelo de. Contrato de Seguro. São Paulo: Campinas, 2002.

PEREIRA, Caio Mário da Silva. Instituições de Direito Civil. 11. ed. Rio de Janeiro: Forense, 2003. v. 3.

PLANIOL, Marcel; RIPERT, Georges. Traité Pratique de Droit Civil Français. Paris: L.GDJ, 1932.

RIDLEY, Matt. Genoma. Rio de Janeiro: Record, 2001.

ROCHA, Sílvio Luis Ferreira da. Curso Avançado de Direito Civil. São Paulo: Revista dos Tribunais, 2002. v. 3.

SANTOS, Amílcar. Seguro. Rio de Janeiro: Record, 1959.

SILVA, Clóvis V. do Couto e. A Obrigação como Processo. São Paulo: José Bushatsky, 1976.

STIGLITZ, Rubén S. Derecho de Seguros. Buenos Aires: Abeledo-Perrot, 1997. v. 2. 
TZIRULNIK, Ernesto; CAVALCANTI, Flávio de Queiroz B.; PIMENTEL, Ayrton. $O$ Contrato de Seguro de acordo com o novo Código Civil Brasileiro. 2. ed. São Paulo: Revista dos Tribunais, 2003.

VASQUES, José. Contrato de Seguro. Coimbra: Coimbra, 1999.

VELJANOVSKI, Cento. A Economia do Direito e da Lei. Rio de Janeiro: Instituto Liberal, 1994.

VIVANTE, Cesare. Del Contratto di Assicurazione. Torino: Unione Tipográfico Editrice Torinese, 1936.

WALD, Arnold. Obrigações e Contratos. 12. ed. São Paulo: Revista dos Tribunais, 1995. 